\title{
Jurist-Diction
}

Volume 4 No. 5 September 202

\section{Kewenangan BNN dalam Pemberian Rehabilitasi Pada Pecandu Narkotika}

\author{
Satriyo Bagus Arianto \\ satriobagusarianto@rocketmail.com \\ Universitas Airlangga
}

How to cite:

Satriyo Bagus Arianto,

'Kewenangan BNN Dalam

Pemberian Rehabilitasi Pada

Pecandu Narkotika' (2021) Vol.

4 No. 5 Jurist-Diction.

Histori artikel:

Submit 17 Juli 2021;

Diterima 15 Agustus 2021;

Diterbitkan 1 September 2021.

DOI:

10.20473/jd.v4i5.29832

p-ISSN: $2721-8392$

e-ISSN: 2655-8297

\section{Abstract}

This research entitled "BNN authority in giving rehabilitation to narcotic addicts", This study employs doctrinal method by using statute approach and conseptual approach. The purpose of this research is to analyze research question in this study. There are two research questions in this study, they are: (1) Does BNN have the authority to give rehabilitation to narcotic addicts?, (2) what's the basic consideration for BNN in giving rehabilitation to narcotic addicts?. This study concludes that BNN authority to give rehabilitation has derived a concept of authority to BNN based on special classification on rehabilitation. There are two category of special classification on rehabilitation. It consists of voluntary (narcotic addicts voluntarily reports themselves) and compulsory (narcotic addicts being caught by investigator). The compulsory category is divided into three parts which include rehabilitation given during court process, rehabilitation given outside court process and rehabilitation given after court decision or court injunction where investigator usually give rehabilitation after court decision or court injuction.

Keywords: BNN Authority; Rehabilitation; Narcotic Addicts.

\begin{abstract}
Abstrak
Penelitian ini berjudul "Kewenangan BNN Dalam Pemberian Rehabilitasi Pada Pecandu Narkotika". Dalam penelitian yang menggunakan metode doktrinal dilakukan dengan menggunakan pendekatan perundang-undangan (statute approach) dan pendekatan konseptual (conseptual approach) dengan tujuan untuk menganalisis rumusan masalah penelitian ini. Terdapat dua rumusan masalah dalam penelitian ini, yaitu (1) Apakah BNN mempunyai kewenangan untuk memberikan rehabilitasi pada pecandu narkotika?; (2) Apa yang menjadi dasar pertimbangan BNN dalam pemberian rehabilitasi pada pecandu narkotika?. Dari penelitian ini dapat disimpulkan bahwa kewenangan BNN untuk memberikan rehabilitasi menghasilkan suatu konsep kewenangan BNN berdasarkan klasifikasi rehabilitasi secara khusus. Terdapat dua klasifikasi rehabilitasi secara khusus yaitu secara voluntary (pecandu melaporkan diri) dan compulsory (pecandu tertangkap tangan oleh penyidik) dimana pada kategori compulsory dibagi menjadi tiga jenis yaitu, 1. Rehabilitasi yang diberikan selama proses peradilan (penyidikan, penuntutan dan persidangan di pengadilan); 2. Rehabilitasi diluar proses peradilan; 3 . Rehabilitasi yang diberikan setelah putusan atau penetapan pengadilan dimana penyidik biasa memberikan rehabilitasi setelah adanya putusan atau penetapan pengadilan.

Kata Kunci: Kewenangan BNN; Rehabilitasi; Pecandu Narkotika.
\end{abstract}




\section{Pendahuluan}

Maraknya peredaran narkotika bertambah banyak dari tahun ke tahun. Penangkapan yang dilakukan baik oleh Badan Narkotika Nasional (BNN) maupun oleh Kepolisian Republik Indonesia (Polri) membuat pengaturan regulasi semakin kompleks. Hal ini dikarenakan semakin banyak pecandu narkotika sampai dengan meningkatnya narkotika jenis baru. Masyarakat menjadi resah dan merasa tidak aman. Melihat hal tersebut, Narkotika menjadi suatu persoalan kenegaraan yang penting untuk dibahas karena keadaan yang berada dalam level mengkhawatirkan.

Undang-Undang Nomor 35 Tahun 2009 tentang Narkotika yang menjadi Undang-Undang baru menggantikan Undang-Undang Nomor 22 Tahun 1997, tidaklah cukup untuk membantu penegak hukum dalam melaksanakan tugasnya. Maka dari itu, dibuatlah peraturan seperti Peraturan Pemerintah, Peraturan Presiden, Peraturan Kepala BNN, Surat Edaran Mahkamah Agung, dan lainnya untuk membantu penegak hukum dalam upaya mereka melaksanakan tugasnya.

Dalam tugas memberantas narkotika, terdapat dua lembaga yang berwenang yaitu Polri dan BNN. Mereka berwenang melakukan penyelidikan, penyidikan, penyadapan dan hal-hal berkaitan dengan kewenangan tersebut sehingga tugas dalam memberantas narkotika dapat terlaksana. Namun terdapat satu kewenangan yang mutlak milik BNN selain hakim (yang selanjutnya juga akan dibahas secara mendalam dalam bab selanjutnya) yaitu pemberian rehabilitasi.

Rehabilitasi dalam lingkup Tindak Pidana Narkotika merupakan bentuk pemulihan bagi pecandu maupun korban penyalahgunaan narkotika dari ketergantungan narkotika agar dapat kembali ke masyarakat. Dalam UndangUndang Narkotika terdapat dua macam rehabilitasi yaitu, Rehabilitasi Medis dan Rehabilitasi Sosial.

Dalam pasal 1 angka (16) Undang-Undang Narkotika menjelaskan bahwa Rehabilitasi Medis adalah suatu proses kegiatan pengobatan secara terpadu untuk membebaskan pecandu dari ketergantungan narkotika. ${ }^{1}$ Rehabilitasi Medis

\footnotetext{
${ }^{1}$ Undang-Undang Nomor 35 Tahun 2009 tentang Narkotika.
} 
dilakukan di rumah sakit yang ditunjuk oleh Menteri atau dapat dilakukan di lembaga rehabilitasi tertentu yang diselenggarakan oleh instansi pemerintah atau masyarakat apabila lembaga rehabilitasi tersebut mendapat persetujuan menteri, sesuai dengan pasal 56 Undang-Undang Narkotika.

Sedangkan Rehabilitasi Sosial, memiliki pengertian dalam pasal 1 angka (17) Undang-Undang Narkotika adalah suatu proses kegiatan pemulihan secara terpadu, baik fisik, mental maupun sosial, agar bekas pecandu narkotika dapat kembali melaksanakan fungsi sosial dalam kehidupan masyarakat. ${ }^{2}$ Mengacu pada pasal 57 Undang-Undang Narkotika, Rehabilitasi Sosial dilakukan melalui pendekatan keagamaan dan tradisional yang dapat dilakukan pecandu pada instansi pemerintah atau masyarakat. Rehabilitasi sosial sama pentingnya dengan rehabilitasi medis, dikarenakan pecandu butuh sebuah pengobatan pikiran yang membuatnya dapat terjalin kembali fungsi sosial dalam bermasyarakat.

Manfaat yang terkandung dalam rehabilitasi dari sisi kesehatan personal pecandu narkotika sampai sisi sosial berujung pada keamanan dan ketertiban masyarakat dimana pecandu narkotika telah melepaskan ketergantungan terhadap narkotika dengan tambahan terbebas dari penyakit akibat mengonsumsi narkotika dan sehat dalam kondisi mental melalui pengobatan pikiran membuat pecandu narkotika siap kembali dalam bermasyarakat dengan kualitas hidup mereka yang meningkat.

Jika dilihat dalam pasal 54 Undang-Undang Narkotika, Rehabilitasi bersifat wajib untuk dijalankan bagi pecandu narkotika. ${ }^{3}$ Rehabilitasi dalam UndangUndang Narkotika diberikan setelah adanya putusan atau penetapan pengadilan. Namun dalam peraturan perundang-undangan dan dalam prakteknya, ditemukan terdapat rehabilitasi yang diberikan tanpa proses panjang peradilan sampai dengan putusan atau penetapan pengadilan. Rehabilitasi tersebut memberikan kesempatan bagi pecandu narkotika dan lembaga penegak hukum untuk tidak membuang waktu apabila memang benar bahwa status tersangka adalah pecandu narkotika tanpa merangkap pengedar. Selain itu rehabilitasi tersebut memberikan kewenangan 
kepada BNN sebagai akibat dari pasal 55 ayat (3) Undang-Undang Narkotika yang melahirkan peraturan pelaksana sebagai dasar dari jenis rehabilitasi disamping rehabilitasi dengan putusan atau penetapan pengadilan. Hal ini perlu diketahui guna mengetahui bahwa BNN tidak hanya memiliki kewenangan menangkap dan menyidik saja melainkan memberikan rehabilitasi sesuai dengan amanat dari Undang-Undang Narkotika. Kewenangan pemberian rehabilitasi tersebut tentunya akan menggunakan dasar pertimbangan yang akan dipakai BNN sebagai pedoman yang diterapkan pada pecandu narkotika.

\section{Kewenangan BNN Memberikan Rehabilitasi Pada Pecandu Narkotika}

Rehabilitasi pada pecandu narkotika diatur dalam peraturan perundangundangan. Pengaturan rehabilitasiadalah guna pecandunarkotika untuk mendapatkan pengobatan sebagaimana kewajiban pecandu narkotika akibat penggunaan narkotika tidak sesuai dengan haknya. Dalam Undang-Undang Narkotika, pengaturan rehabilitasi pada pecandu narkotika diatur sesuai dengan jenis yang ada dan diatur didalamnya. Terdapat dua jenis yang tercantum yaitu wajib lapor dan putusan atau penetapan pengadilan. Namun dalam teori dan praktiknya jenis yang tercantum dan kewenangan $\mathrm{BNN}$ tersebut dalam pemberian rehabilitasi pada pecandu narkotika menjadi luas sebagaimana diatur dalam peraturan pelaksananya.

Dalam pasal 55 ayat (3) Undang-Undang Narkotika bahwa dalam pelaksanaan wajib lapor diatur lebih lanjut dalam peraturan pemerintah, ${ }^{4}$ yang telah diketahui telah diatur dalam Peraturan Pemerintah Nomor 25 Tahun 2011 tentang Pelaksanaan Wajib Lapor Pecandu Narkotika. Peraturan Pemerintah Wajib Lapor menjadi amanat Undang-Undang Narkotika dalam pelaksanaan pemberian rehabilitasi dengan peraturan perundang-undangan lainnya yang berfungsi sebagai akomodasi dari Peraturan Pemerintah Wajib Lapor, yaitu Peraturan Kepala BNN Nomor 11 Tahun 2014 Tentang Tata Cara Penanganan Tersangka dan/atau Terdakwa Pecandu Narkotika dan Korban Penyalahgunaan Narkotika ke dalam Lembaga Rehabilitasi.

${ }^{4}$ ibid. 
Hal ini dikarenakan dalam pasal 13 ayat (3) Peraturan Pemerintah Wajib Lapor tidak mengatur secara jelas bagaimana prosedur pemberian rehabilitasi terhadap jenis yang akan dibahas.

Jenis rehabilitasi tidak serta merta hanya terdapat dua jenis sebagaimana dijelaskanmengenaipengaturanrehabilitasiyang dijelaskansebelumnya. Rehabilitasi pada pecandu narkotika dapat dikategorikan menjadi dua yaitu rehabilitasi secara voluntary dan compulsory. ${ }^{5}$ Kategori ini dikelompokkan berdasarkan mekanisme yang ada. Pada kategori pertama yaitu secara voluntary dilakukan secara sukarela oleh pecandu narkotika sedangkan pada kategori kedua yaitu secara compulsory dilakukan kepada pecandu narkotika yang tertangkap tangan oleh penyidik.

Rehabilitasi secara voluntary (sukarela) dengan mekanisme Wajib Lapor. Mekanisme Wajib Lapor. Mekanisme wajib lapor adalah mekanisme yang dilakukan sendiri oleh pecandu narkotika yang telah cukup umur atau keluarganya dan orang tua atau wali pada pecandu narkotika yang belum cukup umur dengan sukarela datang ke Institusi Penerima Wajib Lapor/IPWL, ${ }^{6}$ yang berperan sebagai penerima laporan dari wajib lapor namun pecandu narkotika dapat juga melakukan kepada institusi selain IPWL dengan nantinya institusi tersebut akan memberikan laporan tersebut kepada IPWL dengan data diri pecandu narkotika dan pemeriksaan awal tanda vital oleh dokter jaga (apabila dilakukan pada institusi BNN). ${ }^{7}$ Sedangkan jika dilakukan pada institusi penerima wajib lapor langsung maka akan diproses oleh institusi ini langsung. Institusi Penerima Wajib Lapor (IPWL) adalah pusat kesehatan masyarakat, rumah sakit, dan/atau lembaga rehabilitasi medis dan lembaga rehabilitasi sosial yang ditunjuk oleh Pemerintah. ${ }^{8}$

\footnotetext{
${ }^{5}$ Muhammad Manfaluthfi Riyadi, 'Implementasi Pelaksanaan Rehabilitasi Bagi Pecandu Narkotika dan Korban Penyalahgunaan Narkotika' (Program Sarjana Universitas Airlangga 2015).[24].

${ }^{6}$ Peraturan Pemerintah Nomor 25 Tahun 2011 tentang Pelaksanaan Wajib Lapor Pecandu Narkotika.

${ }^{7}$ Simon Hermawan Baskoro, 'Rehabilitasi Sebagai Upaya Perlindungan Hukum Terhadap Pengguna Narkotika (Studi Kasus BNNP Jawa Tengah)' (Program Sarjana Universitas Katolik Soegijapranata 2017).[72].

${ }^{8}$ Peraturan Pemerintah, Loc.Cit.
} 
Fasilitas yang tersebar oleh IPWL ditunjuk pemerintah lewat menteri terkait yaitu menteri kesehatan dan menteri sosial, namun hal ini tidak melarang BNN untuk membuat fasilitas untuk menjadi IPWL. ${ }^{9}$ Hal ini diatur dalam Peraturan Pemerintah Wajib Lapor pasal 5 mengenai syarat-syarat yang harus dipenuhi agar bisa menjadi IPWL sebelum dapat ditunjuk pemerintah sehingga memberi kewenangan pada BNN untuk memberikan layanan rehabilitasi apabila telah memenuhi syarat tersebut.

Tahap pemeriksaan atau biasa disebut asesmen meliputi aspek medis dan sosial. Berdasarkan pasal 8 Peraturan Pemerintah Wajib Lapor, aspek-aspek terkait tersebut akan dilakukan pada suatu pemeriksaan yang dilakukan dengan wawancara, observasi, pemeriksaan fisik dan psikis pada pecandu narkotika. ${ }^{10}$ Dalam wawancara meliputi riwayat kesehatan, riwayat penggunaan narkotika, riwayat pengobatan dan perawatan, riwayat keterlibatan pada tindak kriminalitas, riwayat psikiatris, dan riwayat keluarga dan sosial pecandu narkotika. Dalam observasi meliputi pada perilaku pecandu narkotika. Perilaku tersebut diidentifikasi agar dapat dirujuk sebagai indikasi bahwa seorang yang melakukan wajib lapor memang pecandu narkotika. Dalam pemeriksaan fisik dilakukan meliputi spot check, penggeledahan dan tes urin. Sedangkan dalam pemeriksaan psikis dilakukan dengan observasi dan wawancara. Hasil asesmen yang disimpulkan dari asesmen yang dilakukan akan digunakan sebagai dasar menyusun rencana rehabilitasi pada pecandu narkotika tersebut yang nantinya akan dilakukan kesepakatan dengan yang melakukan wajib lapor antara yang melakukan wajib lapor yaitu pecandu narkotika, orang tua, wali atau keluarga pecandu narkotika dan pimpinan institusi penerima wajib lapor. Semua rencana rehabilitasi yang disepakati, dilakukan oleh pecandu narkotika harus wajib lapor kepada institusi penerima wajib lapor. Hal ini guna mencegah penyimpangan dalam pelaksanaan rehabilitasi oleh pecandu narkotika.

9 'Perspektif Penerima Layanan Wajib Lapor (Provider) Terhadap Peraturan Wajib Lapor dan Institusi Penerima Wajib Lapor (IPWL)' (Atmajaya 2012) < arc-atmajaya.org>, accessed 07 November 2019.

${ }^{10}$ Peraturan Pemerintah, Loc.Cit. 
Dengan melaporkan kepada IPWL dan menjalani proses sampai pelaksanaan rencana rehabilitasi, pecandu narkotika akan mendapatkan kartu lapor diri. Kartu ini memiliki fungsi sebagai tanda bukti bahwa pecandu narkotika telah melaporkan diri. Kartu ini adalah memiliki fungsi selain sebagai tanda bukti juga bilamana pecandu tertangkap oleh penyidik Polri atau BNN sehingga tidak dapat dituntut pidana namun wajib melaksanakan rehabilitasi. Kartu lapor diri memiliki limitasi dalam pelaksanaan rehabilitasi yaitu dua kali masa perawatan (rehabilitasi). ${ }^{11}$ Sehingga apabila penangkapan ketiga dilakukan pada pecandu narkotika yang telah tertangkap sebanyak dua kali, harus menjalani proses hukum.

Kategori yang kedua adalah Rehabilitasi secara compulsory (paksaan) dibagi menjadi tiga jenis yaitu Rehabilitasi yang diberikan selama proses peradilan (penyidikan, penuntutan dan pemeriksaan di pengadilan), Rehabilitasi yang diberikan diluar proses peradilan dan Rehabilitasi yang diberikan setelah putusan atau penetapan pengadilan.

Rehabilitasi yang diberikan selama proses peradilan adalah rehabilitasi yang diberikan kepada pecandu narkotika yang sedang melalui proses peradilan (penyidikan, penuntutan, pemeriksaan di pengadilan) sebagaimana diatur dalam pasal 55 ayat (3) Undang-Undang Narkotika bahwa dalam pelaksanaan wajib lapor diatur lebih lanjut dalam peraturan pemerintah, yang telah diketahui telah diatur dalam Peraturan Pemerintah Wajib Lapor dan diakomodasi oleh Perka BNN 11/2014. Dalam pasal 8 dan 22 Perka BNN 11/2014, Rehabilitasi tersebut diberikan setelah diminta oleh penyidik, jaksa atau hakim sesuai kewenangan masing-masing pada tingkat peradilan. Pada tingkat penyidikan diberikan kepada penyidik, pada tingkat penuntutan diberikan kepada jaksa dan pada tingkat pemeriksaan di sidang pengadilan diberikan kepada hakim. ${ }^{12}$ Barulah dilakukan suatu asesmen pada pecandu narkotika. Asesmen tersebut dilakukan oleh suatu

\footnotetext{
${ }^{11}$ ibid.

12 Peraturan Kepala BNN Nomor 11 Tahun 2014 tentang Tata Cara Penanganan Tersangka dan/atau Terdakwa Pecandu Narkotika dan Korban Penyalahgunaan Narkotika ke dalam Lembaga Rehabilitasi.
} 
tim bernama tim asesmen terpadu yang terdiri dari tim dokter dan tim hukum. Dalam asesmen akan menghasilkan rekomendasi dari tim asesmen terpadu yang telah melaksanakan asesmen kepada pecandu narkotika yang nantinya rehabilitasi dapat diberikan dan dilakukan di lembaga rehabilitasi atau rumah sakit sesuai dengan rekomendasi yang diberikan. ${ }^{13}$

Rehabilitasi yang diberikan selama proses peradilan sangat penting dikarenakan untuk kepentingan tersangka/terdakwa perlu diberikan rehabilitasi guna pelaksanaan peradilan dapat berjalan lancar. Tetapi, bila penggunaan narkotika dihentikan, ini akan mengubah semua susunan dan keseimbangan kimia tubuh akibat narkotika dan mengganggu pelaksanaan peradilan akibat gejala putus obat yang disebabkan narkotika yang sebelumnya dikonsumsi. ${ }^{14}$

Rehabilitasi yang diberikan diluar proses peradilan adalah rehabilitasi yang diberikan oleh BNN dimana seseorang yang termasuk pecandu narkotika yang tidak melakukan Wajib Lapor sebelumnya, tidak terkait dengan peredaran gelap narkotika serta tidak membawa narkotika dalam jumlah tertentu diproses diluar peradilan. Rehabilitasi ini wajib dilakukan atas dasar pasal 54 UndangUndang Narkotika dengan menggunakan mekanisme sebagaimana diatur dalam pasal 55 Undang-Undang Narkotika. ${ }^{15}$ Mekanisme yang diatur dalam pasal 55 ayat (3) Undang-Undang Narkotika dengan Perka BNN 11/2014 sebagai acuan untuk melaksanakan Peraturan Pemerintah Wajib Lapor pasal 13 ayat (3). Proses pemberian ini hampir sama dengan jenis yang pertama (Rehabilitasi yang diberikan selama proses peradilan). Namun terdapat sedikit perbedaan, yaitu dalam jenis ini hanya diperlukan suatu penangkapan oleh penyidik dan dalam tahap penyidikan.

Pecandu narkotika yang ditangkap atau tertangkap tangan akan dilakukan penyidikan sesuai dengan tahapan kewenangan penyidikan yang dimiliki oleh BNN pada Undang-Undang Narkotika dan Peraturan Presiden Nomor 23 Tahun 2010

\footnotetext{
${ }^{13}$ ibid.

${ }^{14}$ Humas BNN, 'Dampak Langsung Dan Tidak Langsung Penyalahgunaan Narkoba', (BNN, 20 Mar 2014) <https://bnn.go.id/>, accessed 16 Januari 2020.

${ }^{15}$ Wawancara dengan Adi, Subbag Umum BNN Kota Gresik, 13 Agustus 2019.
} 
tentang Badan Narkotika Nasional. Penyidikan tersebut tetaplah dilakukan sebagai akibat untuk membuktikan bahwa tersangka adalah pecandu narkotika sebelum diserahkan pada tim asesmen untuk dimintakan asesmen terhadap tersangka. Dalam asesmen ini dilakukan setelah terbukti positif menggunakan narkotika sesuai dengan tes urine, darah, rambut, dan/atau DNA yang dilakukan oleh penyidik. Asesmen yang dilakukan oleh tim asesmen terpadu mempunyai tugas selain tugas dari tim dokter yaitu analisis medis, psikososial, serta merekomendasi rencana terapi dan rehabilitasi, terdapat tugas tim hukum untuk melakukan analisis terhadap seseorang yang ditangkap dan/atau tertangkap tangan dalam kaitan penyalahgunaan dan peredaran gelap narkotika. Hasil asesmen dalam rekomendasi menghasilkan peran tersangka dan rencana rehabilitasi. ${ }^{16}$

Pelaksanaan rekomendasi dapat dilaksanakan setelah dilaporkan secara tertulis dan ditetapkan pengadilan negeri setempat. ${ }^{17}$ Hasil pelaksanaan rekomedasi tersebut bergantung pada berita acara pemeriksaan hasil laboratorium dan berita acara pemeriksaan oleh penyidik, hal ini merujuk pada pasal 4 Perka BNN 11/2014 yang merupakan akomodasi pasal 13 ayat (3) Peraturan Pemerintah Wajib Lapor sebagaimana perintah dari Undang-Undang Narkotika bahwa untuk dapat ditempatkan dalam lembaga rehabilitasi yang dikelola oleh pemerintah membutuhkan tiga hal yaitu berita acara pemeriksaan hasil laboratorium, berita acara pemeriksaan oleh penyidik dan rekomendasi tim asesmen terpadu. Rekomendasi ini dapat digunakan penyidik untuk menentukan apakah tersangka layak direhabilitasi atau tidak dan perlu diteruskan proses hukumnya atau tidak dengan diketahuinya peran tersangka tersebut, tidak serta merta bahwa rekomendasi tim asesmen terpadu telah menjalankan tugasnya dan telah mendapat penetapan oleh pengadilan negeri setempat. Namun rekomendasi ini layak dipertimbangkan oleh penyidik karena dibuat oleh tim asesmen terpadu yang terdiri dari tim dokter dan tim hukum yang berasal dari unsur-unsur yang membentuk tim tersebut yaitu tim dokter yang terdiri dari dokter dan psikolog dan tim hukum yang terdiri dari Polri, BNN, Kejaksaan dan kementerian hukum dan HAM.

\footnotetext{
${ }^{16}$ Peraturan Kepala BNN, Loc.Cit.

${ }^{17}$ ibid.
} 
Pemberian rehabilitasi ini dinamakan diluar proses peradilan karena hal ini dapat diberikan oleh penyidik walau proses hukum tidak berlanjut sampai di pengadilan karena pemberian ini bergantung pada berita acara pemeriksaan oleh penyidik serta berita acara pemeriksaan hasil laboratorium. Hal ini dilakukan dikarenakan rekomendasi hanya sebatas asesmen internal sehingga diperlukan berita acara pemeriksaan oleh penyidik dan berita acara pemeriksaan hasil laboratorium sebagai pendukung bahwa rekomendasi dapat dilaksanakan. Dikatakan demikian karena perlu pertimbangan juga dari penyidik mengenai tersangka dari kehidupan tersangka dari alat bukti (misalkan keterangan tetangga mengenai kehidupan tersangka atau alat bukti lainnya) bahwa peran tersangka tidaklah lebih dari seorang pecandu.

Rehabilitasi yang diberikan setelah putusan atau penetapan pengadilan adalah rehabilitasi yang diberikan oleh hakim kepada pecandu narkotika yang terbukti bersalah atau tidak bersalah melalui putusan atau penetapan pengadilan sesuai dengan yang diatur dalam pasal 127 Undang-Undang Narkotika. Dalam jenis ini, pecandu narkotika menjalani proses peradilan sampai dengan putusan atau penetapan pengadilan. Putusan atau penetapan pengadilan menjadi pilihan bagi penyidik karena penyidik tidak bisa serta merta memberikan rehabilitasi tanpa berbagai pertimbangan dengan salah satunya rekomendasi tim asesmen terpadu.

Dalam tahap putusan dilakukan hakim dengan pertimbangan sesuai ketentuan Surat Edaran Mahkamah Agung Nomor 4 Tahun 2010 tentang Penempatan Penyalahgunaan, Korban Penyalahgunaan Dan Pecandu Narkotika Ke Dalam Lembaga Rehabilitasi Medis dan Rehabilitasi Sosial, yang bahwa pertimbangan tersebut hakim dapat memutuskan atau menetapkan apakah terdakwa adalah hanya pecandu narkotika ataukah merangkap sebagai pengedar atau malah merupakan korban penyalahgunaan narkotika sesuai dengan pemeriksaan di pengadilan. Putusan atau penetapan pengadilan yang memberikan rehabilitasi bagi terdakwa akan diperhitungan sebagai masa menjalani hukuman. Dalam pelaksanaan, putusan atau penetapan dilaksanakan sesuai dengan rekomendasi tim asesmen terpadu 
dan surat keterangan dari penyidik sesuai ketentuan SEMA 4/2010. ${ }^{18}$ Dalam hal ini penyidik menjadi salah satu yang berwenang untuk memberikan pertimbangan rehabilitasi, dengan dilampirkan hasil rekomendasi tim asesmen terpadu yang telah dimohonkan sebelumnya ${ }^{19}$ dan surat keterangan dari penyidik..$^{20}$

Dari dua kategori yang menghasilkan berbagai jenis, dapat diketahui bahwa dalam kategori Voluntary bahwa BNN dalam kewenangannya pada IPWL hanya sebatas pendirian dan pengelolaan dengan koordinasi instansi terkait. Sedangkan dalam kategori compulsory bergantung dalam suatu hasil rekomendasi yang dikeluarkan oleh tim asesmen terpadu. Tim asesmen terpadu menjadi inti dari pemberian rehabilitasi dan tim ini adalah kewenangan BNN. Bagi BNN sebagaimana mandat Undang-Undang Narkotika dan peraturan dibawahnya yang mengatur maka jika ada seseorang yang ditangkap dan ada indikasi pengguna narkotika maka akan dimintakan assesment oleh penyidik. Assesment akan dilakukan oleh sejumlah pihak yaitu psikiater, psikolog, medik, polisi, BNN dan jaksa. Jika hasil assement terbukti pengguna narkotika murni maka tidak memenuhi syarat untuk dilakukan penahanan dan akan ditempatkan direhabilitasi. ${ }^{21}$

Terdapat dua alasan mengapa kewenangan rehabilitasi milik BNN. Pertama, berdasarkan pasal 1 angka 6 bahwa tim yang terdiri dari tim dokter dan tim hukum ditetapkan oleh pimpinan kerja suatu tempat berdasarkan Surat Keputusan Kepala BNN, BNNP dan BNN Kota/Kabupaten. Tim ini dibuat atas dasar kewenangan BNN yang dituangkan dalam Perka BNN. Kedua, berdasarkan pasal 11 ayat (1) bahwa tim asesmen terpadu secara berjenjang harus berkoordinasi dengan BNN, BNN Provinsi dan BNN Kota/Kabupaten perihal hasil asesmen. Hasil asesmen dikeluarkan dalam bentuk rekomendasi bahwa seorang pengguna tersebut apakah

\footnotetext{
${ }^{18}$ Wawancara dengan Achmad Subaidi, Hakim Tinggi Pengadilan Tinggi Kota Surabaya, 21 Oktober 2019.

${ }^{19}$ Muslikan, [et.,al.], 'Pelaksanaan Assesmen Tentang Rehabilitasi Terhadap Korban Penyalahgunaan Narkotika Ditinjau Dari Peraturan Perundang-Undangan’ (2019) 11 Living Law.[75].

${ }^{20}$ Hakim Tinggi, Loc.Cit.

${ }^{21}$ Widi Al Adiyat, 'Kewenangan Badan Narkotika Nasional (BNN) Dan Badan Reserse Kriminal (BARESKRIM) POLRI Dalam Penyidikan Kasus Narkotika' (2018) Journal of Undergraduate Thesis Fakultas Hukum Universitas Muhammadiyah Jember.[6].
} 
merangkap sebagai pengedar atau murni sebagai pecandu saja. Tim asesmen terpadu juga akan merekomendasi rencana rehabilitasinya. ${ }^{22}$ Untuk itu dibutuhkan koordinasi dengan BNN mengingat BNN yang membentuk tim asesmen terpadu dan bertanggung jawab pada presiden.

Kewenangan BNN tersebut terbentuk dari Surat Keputusan Kepala BNN, BNNP dan BNN Kota/Kabupaten yang membentuk tim asesmen terpadu. Tim asesmen terpadu terikat pada pertanggungjawaban BNN, BNNP, dan BNN Kota/ Kabupaten dimana diatur dalam pasal 11 ayat (1) Perka BNN yang mengharuskan koordinasi dengan BNN, BNNP, BNN Kota/Kabupaten, karena rekomendasi yang dikeluarkan akan dipertanggungjawabkan pada presiden sebagaimana diatur dalam pasal 64 UU Narkotika.

\section{Dasar Pertimbangan BNN Dalam Pemberian Rehabilitasi Pada Pecandu Narkotika}

Dasar pertimbangan pemberian rehabilitasi diberikan berdasarkan asesmen yang dilakukan tergantung dari klasifikasi khusus pemberian rehabilitasi berdasarkan mekanisme yang digolongkan dalam dua kategori yaitu secara voluntary dan compulsory. Penggolongan mekanisme secara voluntary apabila pecandu melaporkan diri ke IPWL dan secara compulsory apabila pecandu tertangkap tangan oleh penyidik sehingga mekanisme yang berbeda membuat dasar pertimbangan menjadi berbeda pula.

Pada kategori pertama yaitu secara voluntary, pemberian rehabilitasi berdasarkan kategori ini memakai dasar pertimbangan melalui pemeriksaan oleh IPWL. Dasar pertimbangan itu akan dilakukan dengan wawancara, observasi, pemeriksaan fisik dan psikis. Hal ini dilakukan guna mengetahui metode rehabilitasi apa yang akan dijalani pengguna, termasuk berapa lama akan direhabilitasi. ${ }^{23}$ Ada berbagai pertanyaan yang

${ }^{22}$ Ratna WP, Aspek Pidana Penyalahgunaan Narkotika Rehabilitasi Versus Penjara (Menyoroti Pasal 127 UU No. 35 Tahun 2009) (Legality 2017).[90].

${ }^{23}$ Zoraya Ralie, 'Tahapan dan Proses Rehabilitasi Penyalahguna Narkoba' ([s.n], 2017) <beritagar.id>, accessed 12 November 2019 
akan diajukan dalam proses ini (proses wawancara, observasi, pemeriksaan fisik dan psikis). Selain dengan yang disebutkan dalam pasal 8 ayat (2) Peraturan Pemerintah Wajib lapor terdapat beberapa pertanyaan yang menjadi dasar utama pertimbangan dalam perencanaan dan pemberian rehabilitasi misalnya kapan mulai penggunaan narkotika, bagaimana intensitasnya, sampai perasaan yang dialami ketika memakai narkotika termasuk menganalisis apakah yang bersangkutan terlibat jaringan atau tidak. ${ }^{24}$ Pertanyaan tersebut adalah sebagian yang ditanyakan untuk menjadi dasar pertimbangan dalam perencanaan dan pemberian rehabilitasi oleh IPWL. Selebihnya adalah observasi atas perilaku pecandu narkotika sebagai acuan dalam perencanaan rehabilitasi apa yang cocok untuk pecandu narkotika.

Dasar pertimbangan pada kategori kedua yaitu secara compulsory yang terdiri dari Rehabilitasi yang diberikan selama proses peradilan (penyidikan, penuntutan dan persidangan di pengadilan), Rehabilitasi yang diberikan diluar proses peradilan dan Rehabilitasi yang diberikan setelah putusan atau penetapan pengadilan berdasarkan asesmen oleh tim asesmen terpadu dengan ukuran jumlah narkotika yang dibawa mengikuti SEMA 4/2010 sebagai pedoman bagi penyidik, jaksa dan hakim. ${ }^{25}$ Hal ini dikarenakan belum ada aturan yang mengatur pada penyidik dan jaksa mengenai ukuran jumlah narkotika yang dibawa agar dapat dikatakan hanya sebagai pecandu narkotika atau korban penyalahgunaan narkotika, karena SEMA 4/2010 keberlakuannya adalah untuk hakim.

Dalam SEMA 4/2010 tentang Penempatan Penyalahgunaan, Korban Penyalahgunaan dan Pecandu Narkotika ke Dalam Lembaga Rehabilitasi menyebutkan lima syarat untuk mendapatkan pemidanaan berupa rehabilitasi. ${ }^{26}$ Syarat pertama, penangkapan terhadap terdakwa dilakukan secara tertangkap tangan dengan syarat kedua, pada saat tertangkap tangan tersebut ditemukan barang bukti pemakaian 1 hari narkotika dengan jenis dan bobot tertentu antara lain:

\footnotetext{
${ }^{24}$ ibid.

${ }^{25}$ Hakim Tinggi Pengadilan Tinggi Kota Surabaya, Loc.Cit.

${ }^{26}$ Husein Abdulsalam, 'Dilema Hukuman Rehabilitasi Narkoba' (Tirto 2017) <tirto.id>, 3 September 2017, accessed 12 November 2019.
} 
1. Kelompok metamphetamine (shabu) : 1 gram

2. Kelompok MDMA (ekstasi) : 2,4 gram atau sama dengan 8 butir

3. Kelompok Heroin : 1,8 gram

4. Kelompok Kokain : 1,8 gram

5. Kelompok Ganja : 5 gram

6. Daun Koka : 5 gram

7. Meskalin : 5 gram

8. Kelompok Psilosybin : 3 gram

9. Kelompok LSD (d-lysergic acid diethylamide) : 2 gram

10. Kelompok PCP (phencylidine) : 3 gram

11. Kelompok Fentanil : 1 gram

12. Kelompok Metadon : 0,5 gram

13. Kelompok Morfin : 1,8 gram

14. Kelompok Petidin : 0,96 gram

15. Kelompok Kodein : 72 gram

16. Kelompok Bufrenorfin : $32 \mathrm{mg}$

Syarat yang ketiga dan keempat juga mengharuskan terbitnya surat uji laboratorium dengan hasil pemeriksaan positif menggunakan narkotika atas permintaan penyidik dalam hal ini dapat dikatakan bahwa berdasarkan rekomendasi tim asesmen terpadu dengan diikuti surat keterangan dari dokter jiwa/psikiater pemerintah yang ditunjuk oleh hakim. ${ }^{27}$

Sedangkan yang kelima, tidak terdapat bukti bahwa yang bersangkutan terlibat dalam peredaran gelap narkotika. Ini dibuktikan dalam persidangan dengan bukti yang diberikan oleh penyidik, jaksa atau pihak terdakwa untuk menentukan peran tersangka apabila rekomendasi tim asesmen terpadu diragukan untuk menjadi acuan dalam menentukan peran pecandu narkotika. ${ }^{28}$

Tim Asesmen Terpadu terdiri atas Tim dokter dan Tim hukum yang masingmasing memiliki tugas dan fungsi tersendiri. Analisis hukum yang bertujuan untuk mendapat informasi faktor penyebab dan jangka waktu penyalahgunaan narkotika serta keterkaitan dengan peredaran narkotika dilakukan oleh Tim hukum. ${ }^{29}$

\footnotetext{
${ }^{27}$ Surat Edaran Mahkamah Agung Republik Indonesia Nomor 04 Tahun 2010 tentang Penempatan Penyalahgunaan, Korban Penyalahgunaan Dan Pecandu Narkotika Ke Dalam Lembaga Rehabilitasi Medis Dan Rehabilitasi Sosial.

${ }^{28}$ ibid.

${ }^{29}$ Rama Manggala Utama Putra, 'Penerapan Asesmen Terpadu Dalam Penegakan Hukum Terhadap Penyalah Guna Narkotika', (Program Pascasarjana Universitas Lampung 2017).[94].
} 
Lalu, analisis medis untuk mendapatkan gambaran klinis baik fisik maupun psikis dari kondisi penyalahguna yang bertujuan untuk menentukan taraf ketergantungan serta merencanakan tindakan rehabilitasi yang tepat bagi penyalahguna. ${ }^{30}$

Rekomendasi tim asesmen terpadu berisi keterangan mengenai peran tersangka dan/atau terdakwa dalam tindak pidana narkotika, tingkat ketergantungan pecandu narkotika, rekomendasi kelanjutan proses hukumnya dan tempat serta lama waktu rehabilitasi. ${ }^{31}$

Rekomendasi tim asesmen terpadu berisi keterangan mengenai peran tersangka dan/atau terdakwa dalam tindak pidana narkotika, tingkat ketergantungan penyalahguna narkotika, rekomendasi kelanjutan proses hukumnya dan tempat serta lama waktu rehabilitasi dengan nantinya ditandatangani oleh ketua Tim Asesmen Terpadu dalam hal ini kepala BNN tempat dimana perkara terjadi. ${ }^{32}$

Kedua tim dalam tim asesmen terpadu inilah yang bekerja sama dalam hal proses asesmen terhadap pemohon. Sedangkan dalam pemeriksaan di pengadilan oleh hakim biasanya mempertimbangkan mengenai apakah sudah melakukan IPWL atau belum. Hal ini dijadikan petunjuk oleh hakim karena sebelum memutuskan atau menetapkan rehabilitasi perlu dilihat mengenai status wajib lapornya apakah sudah pernah dilakukan atau belum, sehingga secara singkatnya dasar pertimbangan yang dipakai jika ditarik garis besarnya adalah melalui SEMA 4/2010.

Sehingga dapat disimpulkan bahwa dasar pertimbangan pemberian rehabilitasi pada kedua kategori berbeda dikarenakan mekanisme yang berbeda serta instansi yang memeriksa juga berbeda. Dalam kategori voluntary apabila melewati BNN atau Polri maka pemeriksaan dapat dilakukan BNN atau Polri jika pecandu melaporkan diri kepada BNN atau Polri untuk pemeriksaan awal dan data diri pecandu selebihnya diserahkan pada IPWL untuk pemeriksaan menyeluruh dengan aturan yang mengacu pada peraturan dari menteri kesehatan dan menteri

\footnotetext{
${ }^{30}$ ibid. [95].

${ }^{31}$ ibid. [96].

32 ibid.
} 
sosial. Hal ini dikarenakan IPWL dibawahi menteri kesehatan dan menteri sosial sebagai kewenangan yang diberikan oleh Undang-Undang Narkotika.

Sedangkan dalam kategori compulsory melalui asesmen BNN atau lebih tepatnya tim asesmen terpadu yang dikoordinasi secara berjenjang oleh BNN dengan menggunakan SEMA 4/2010 sebagai acuan asesmen dalam jumlah narkotika. Hal ini dikarenakan tim asesmen terpadu hanya terdiri dari tim medis yaitu dokter dan psikolog dan tim hukum yang terdiri dari tim hukum yaitu BNN, Polri, jaksa dan kemenkumham. Sehingga acuan yang dipakai mengenai jumlah adalah SEMA 4/2010 dalam mengukur peran tersangka apakah hanya sebatas pecandu atau pengedar juga.

\section{Kesimpulan}

Kewenangan BNN pada kategori pertama hanya sebatas pemeriksaan awal dan data diri pecandu narkotika jika pecandu melaporkan diri ke BNN dan merupakan kewenangan Polri jika pecandu melaporkan diri ke Polri serta pendirian IPWL Selebihnya diserahkan pada IPWL yang telah berkoordinasi kepada tenaga medis terkait. Dalam kategori kedua dapat disimpulkan juga terdapat dua jenis yaitu rehabilitasi yang diberikan selama proses peradilan dan diluar proses peradilan, dalam setiap jenisnya terdapat suatu hasil asesmen yang berupa rekomendasi tim asesmen terpadu. Rekomendasi yang dikeluarkan adalah kewenangan BNN yang didapat melalui dibentuknya tim asesmen terpadu yang dikoordinasi oleh BNN dan menjadi pertanggungjawaban lembaga BNN kepada presiden, dengan rekomendasi yang dikeluarkan menjadi alat utama bagi penyidik Polri dan BNN untuk memberikan rehabilitasi karena hasil asesmen berupa rekomendasi yang diberikan oleh tim asesmen terpadu.

Dasar pertimbangan dalam asesmen memakai SEMA Nomor 4 Tahun 2010 yang menjadi pedoman utama dalam mempertimbangkan untuk memberikan rehabilitasi pada pecandu narkotika selain analisis medis yang dilakukan oleh tim dokter dan analisis hukum yang dilakukan oleh tim hukum dalam tim asesmen terpadu. 


\section{Daftar Bacaan}

\section{Buku}

Ratna WP, Aspek Pidana Penyalahgunaan Narkotika Rehabilitasi Versus Penjara (Menyoroti Pasal 127 UU No. 35 Tahun 2009 (Legality 2017).

\section{Jurnal}

Muslikan, [et.,al.], 'Pelaksanaan Assesmen Tentang Rehabilitasi Terhadap Korban Penyalahgunaan Narkotika Ditinjau Dari Peraturan Perundang-Undangan' (2019) 11 Living Law.

Widi Al Adiyat, 'Kewenangan Badan Narkotika Nasional (BNN) Dan Badan Reserse Kriminal (BARESKRIM) POLRI Dalam Penyidikan Kasus Narkotika' (2018) Journal of Undergraduate Thesis Fakultas Hukum Universitas Muhammadiyah Jember.

\section{Laman}

'Perspektif Penerima Layanan Wajib Lapor (Provider) Terhadap Peraturan Wajib Lapor dan Institusi Penerima Wajib Lapor (IPWL)' (Atmajaya 2012), <arcatmajaya.org>, accessed 07 November 2019.

Husein Abdulsalam, 'Dilema Hukuman Rehabilitasi Narkoba' (Tirto 2017), <tirto. id>, 3 September 2017, accessed 12 November 2019.

Zoraya Ralie, 'Tahapan dan Proses Rehabilitasi Penyalahguna Narkoba', ([s.n], 2017), <beritagar.id >, accessed 12 November 2019.

\section{Perundang-undangan}

Undang-Undang Nomor 35 Tahun 2009 tentang Narkotika (Lembaran Negara Republik Indonesia Tahun 2009 Nomor 143).

Peraturan Pemerintah Nomor 25 Tahun 2011 tentang Pelaksanaan Wajib Lapor Pecandu Narkotika (Lembaran Negara Republik Indonesia Tahun 2011 Nomor 46).

Peraturan Kepala BNN Nomor 11 Tahun 2014 tentang Tata Cara Penanganan Tersangka dan/atau Terdakwa Pecandu Narkotika dan Korban Penyalahgunaan Narkotika ke dalam Lembaga Rehabilitasi (Berita Negara Republik Indonesia Nomor 844 Tahun 2014).

Surat Edaran Mahkamah Agung Republik Indonesia Nomor 04 Tahun 2010 tentang Penempatan Penyalahgunaan, Korban Penyalahgunaan Dan Pecandu 
Narkotika Ke Dalam Lembaga Rehabilitasi Medis Dan Rehabilitasi Sosial.

\section{Skripsi}

Muhammad Manfaluthfi Riyadi, 'Implementasi Pelaksanaan Rehabilitasi Bagi Pecandu Narkotika dan Korban Penyalahgunaan Narkotika', (Program Sarjana Universitas Airlangga 2015).

Simon Hermawan Baskoro, 'Rehabilitasi Sebagai Upaya Perlindungan Hukum Terhadap Pengguna Narkotika (Studi Kasus BNNP Jawa Tengah)', (Program Sarjana Universitas Katolik Soegijapranata 2017).

\section{Tesis}

Rama Manggala Utama Putra, 'Penerapan Asesmen Terpadu Dalam Penegakan Hukum Terhadap Penyalah Guna Narkotika', (Program Pascasarjana Universitas Lampung 2017).

\section{Wawancara}

Wawancara dengan Adi, Subbag Umum BNN Kota Gresik, 13 Agustus 2019.

Wawancara dengan Achmad Subaidi, Hakim Tinggi Pengadilan Tinggi Kota Surabaya, 21 Oktober 2019. 